\title{
Quasi-Real-Time Data of the Economic Tendency Survey
}

\author{
Maria Billstam ${ }^{1}$ - Kristina Frändén ${ }^{2}$. \\ Johan Samuelsson ${ }^{1} \cdot$ Pär Österholm ${ }^{3}$
}

\begin{abstract}
Survey data from businesses and households are widely used for forecasting and economic analysis. In Sweden, the most important survey of this kind is the Economic Tendency Survey of the National Institute of Economic Research. A shortcoming with this survey is that real-time data of it largely are unavailable. In this paper, we describe how two quasi-real-time data sets of this survey have been constructed-one monthly and one quarterly. The term "quasi-real-time data" refers to data which are not actual real-time data but have been created in order to provide a close approximation to real-time data. The data sets consist of monthly/ quarterly vintages of the most important series of the survey, including the main confidence indicators. A natural usage of these data sets is evaluations of modelbased forecasts and nowcasts. We illustrate this with an application to Swedish GDP growth. This shows that several of the studied indicators from the Economic Tendency Survey appear to have positive nowcast content for GDP growth.
\end{abstract}

Keywords Data revisions · Nowcasting

JEL Classifications C83 $\cdot$ E17

Pär Österholm

par.osterholm@oru.se

1 National Institute of Economic Research, Stockholm, Sweden

2 Statistics Sweden, Stockholm, Sweden

3 School of Business, Örebro University, 70182 Örebro, Sweden 


\section{Introduction}

The National Institute of Economic Research each month asks representatives of Swedish firms and households about the present economic situation and the outlook for the near future. The information is compiled in the Economic Tendency Survey - a publication whose purpose is to be a timely available source of indicators for key economic variables.

The Economic Tendency Survey is the largest survey of its kind in Sweden. It is widely used for both forecasting and economic analysis concerning the Swedish economy. For those using the survey for such purposes, one problem is that most of the data presented are seasonally adjusted. In addition, a number of variablesprimarily so called confidence indicators-are also standardised to have a mean of 100 and a standard deviation of 10. Such adjustments of the data mean that looking at a time series today, the value that it takes on for a particular point in time is likely to differ from what the value was according to an earlier publication/release. This problem is by no means unique to the Economic Tendency Survey; it is a wellknown issue that researchers are aware that they may have to address when dealing with, for example, national accounts data (which can be substantially revised over time). The natural way to address the problem is to use data that reflect the information that an analyst, policymaker or forecaster would have had access to in real time; see, for example, Diebold and Rudebusch (1991), Croushore and Stark (2001), Orphanides (2001) and Herrmann et al. (2005) for important contributions on this topic. But while the usage of real-time data is the preferred solution to this type of problem, it is not always a feasible one. The typical obstacle to using realtime data is that they simply are not available. In some cases, real-time data can be created by going through historical records but often this is not possible. ${ }^{1}$ For the Economic Tendency Survey, no real-time data set of relevant length exists, nor is it possible to construct one through the historical records. ${ }^{2}$

In this paper we therefore document the creation of two quasi-real-time data sets for the Economic Tendency Survey which we have made publicly available. ${ }^{3}$ By "quasi-real-time data" we mean data which are not actual real-time data but which have been created in order to provide a close approximation to real-time data. For several purposes, this will constitute a good enough approximation to the data that the analyst, forecaster or researcher is interested in. One application for which the quasi-real-time data are highly relevant is the evaluation of models built for nowcasting. We accordingly illustrate the potential usage of the data set with an outof-sample nowcast exercise for Swedish GDP growth in which we rely on data from the Economic Tendency Survey as explanatory variables.

\footnotetext{
${ }^{1}$ Even if it is possible, it might not be realistic in some cases since it may require very large amounts of work.

${ }^{2}$ While there are historical records available - in the form of printed reports - these do not contain the full time series as they looked at each point in time; the typical amount of information concerning each variable is just the last few observations.

3 The data sets can be downloaded from www.konj.se/quasi-real-time-data.
} 
The remainder of this paper is organised as follows: In Sect. 2, we describe the Economic Tendency Survey. The construction of the quasi-real-time data sets is explained in Sect. 3. In Sect. 4, we illustrate the usability of the data by conducting an out-of-sample nowcast exercise for Swedish GDP growth. Finally, Sect. 5 concludes.

\section{The Economic Tendency Survey}

The Economic Tendency Survey of the National Institute of Economic Research is the largest survey of its kind in Sweden, including more than 6000 companies and 1500 households. Below we give a short description of the survey. For more details, the reader is referred to the user guide (National Institute of Economic Research, 2013).

\subsection{Businesses}

Stratified sampling of firms takes place through Statistics Sweden's business register. The companies are divided into four main categories: manufacturing industry, construction industry, trade and private service sector. The questionnaires-which approximately half of the companies nowadays receive in electronic form-are addressed to upper management and the questions relate to the development in recent months, the present situation and the outlook for the near future regarding, for example, output, new orders, employment and prices. For a detailed description of each question, see Appendix 1.

Every third month-in January, April, July and October-the business survey contains more questions; for a detailed description of the questions, see Appendix 2. This is why we generate two data sets, one monthly and one quarterly.

\subsection{Households}

A random net sample of 1500 individuals, between 16 and 84 years of age, are interviewed over the telephone. The questionnaire contains questions concerning both to the household's own economic situation and the aggregate economy. For a detailed description of the questions in this part of the survey, see Appendix 3.

\subsection{Presentation of the Results}

For questions of binominal or multinomial type (where the answers, for example, are increase/unchanged/decrease), the summarised weights for each response alternative are standardised so that the percentages of the response alternatives add up to 100. In order to simplify the presentation of the data, the concepts "net figures" or "balances" are employed (and used equivalently). A net figure/balance is the difference between the share of respondents reporting an increase and a 
decrease for a particular question. For example, if $45 \%$ of respondents report that there has been an increase, $25 \%$ that there has been no change and $30 \%$ that there has been a decrease, the net figure/balance is $45-30=15$. $^{4}$

As an illustration, consider the time series in Fig. 1 which shows the seasonally adjusted net figures for the output volume over the past three months in the manufacturing industry (question BTVI101, see Appendix 1) as given by the Economic Tendency Survey in December 2015. This shows, for example, how in April 2009-as the effects of the global financial crisis were seriously affecting the Swedish economy-there were substantially more companies which had decreased their production relative to those who had increased it. The net figure of almost -40 reflects that approximately $54 \%$ of the companies (weighted share) in the survey stated that they had decreased their production whereas $14 \%$ (weighted share) had increased it; the remaining $32 \%$ (weighted share) had left it unchanged.

Not all series are presented using net figures though. For example, households' inflation expectations at the twelve-month horizon (question Q063, see Appendix 3), which are shown in Fig. 2, are simply given in percent.

Having briefly described the survey, we next turn to the construction of the quasireal-time data sets.

\section{Quasi-Real-Time Data}

The raw data that underlie indicators and individual questions in the Economic Tendency Survey are not revised, except on the relatively rare occasion when an error has to be corrected. This means that for the raw data, the latest data vintage is almost identical to true real-time data (differing only with respect to the corrected errors). ${ }^{5}$ The quasi-real-time data can therefore be generated in a straightforward manner. For each vintage, we conduct the following three steps for individual questions:

(1) Set the sample to the relevant time period.

(2) Copy the raw data of the series.

(3) If applicable: Seasonally adjust the series. ${ }^{6}$

\footnotetext{
${ }^{4}$ It can be noted that when conducting these calculations for the companies, a weighting coefficient is used for each firm representing an aspect of its size-either in terms of employment or value added. Having obtained the results for each stratum, weighting coefficients are used to reflect the relative significance of each stratum in the frame or population.

5 The latest vintage of the survey, which contains the raw data (as well as seasonally adjusted series and indicators), can be downloaded from http://statistik.konj.se/PXWeb/pxweb/en/KonjBar/. It should be noted that these data are always up to date and, accordinlgy, not the ones used in this paper to generate the quasi-real-time data. We used the vintage of December 2015 for the monthly data set and the vintage of October 2015 for the quarterly.

${ }^{6}$ For questions that are not seasonally adjusted or transformed, the latest vintage of data is-just like the case for the raw data-the same as real-time data, except for corrected errors. This applies to, for example, Q050, Q053, Q060, Q063, Q183, Q193 and Q203.
} 


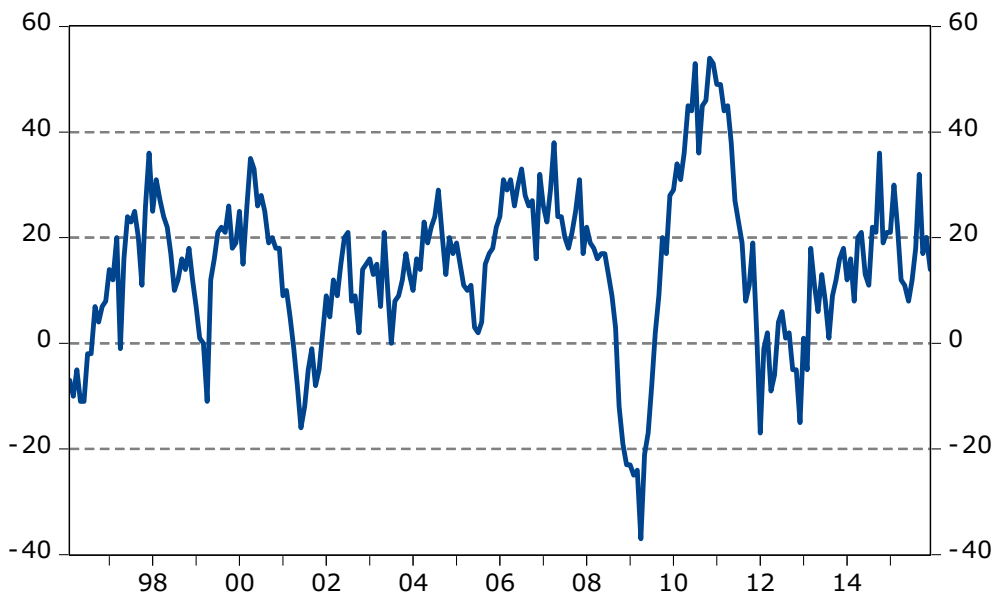

Fig. 1 Output volume over the past 3 months in the manufacturing industry. Note Seasonally adjusted net numbers on the vertical axis. Data are from the Economic Tendency Survey of December 2015

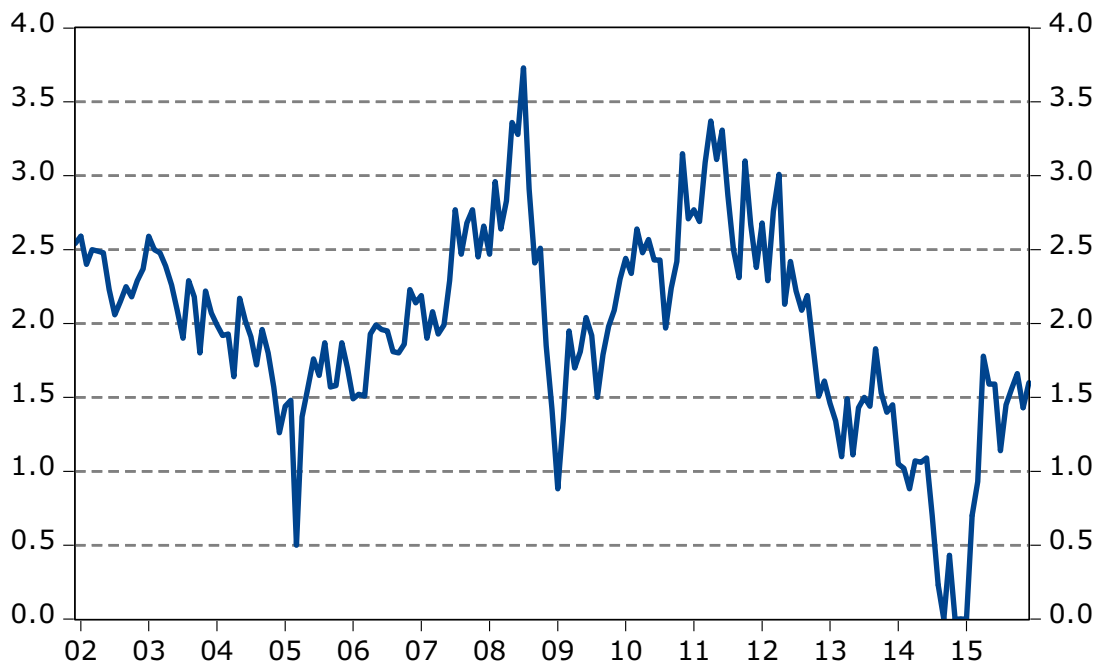

Fig. 2 Households' inflation expectations. Note Percent on the vertical axis. Data are from the Economic Tendency Survey of December 2015

For indicators and other variables that are generated based on two or more series, the following additional steps are conducted: ${ }^{7}$

\footnotetext{
${ }^{7}$ As an exception, the variables with the suffixes "ORDP", "SYSP", "SYSA" and "PRIA" are generated in a sligthly different manner: (1) Set the sample to the relevant time period. (2) Copy the raw data of the series as they appear. (3) Weigh the series together using the appropriate weigths. (4) Seasonally adjust the weighted series.
} 
(4) If applicable: Standardise the series used in the calculation.

(5) Weigh the (potentially standardised) series together using the appropriate weights.

(6) If applicable: Standardise the weighted series. For example, confidence indicators have a mean of 100 and a standard deviation of 10 .

Based on the above method, we generate vintages of time series which show how different variables in the Economic Tendency Survey would have looked in real time if today's methods concerning seasonal adjustment, standardisation and weighing would have been employed. For recent vintages, our method generates data that generally are identical to what proper real-time data would have looked like. For older vintages, on the other hand, there will be differences. The difference will partly be due to methodological changes - such as different methods for seasonal adjustment and different choices concerning standardisation-but also to the above mentioned fact that errors may have been corrected. Whether this difference matters depends on the purpose behind using the data. For example, if one wants to conduct a study of how the Economic Tendency Survey has affected stock prices, the exact information content of the survey in real time is a key issue; the present quasi-realtime data set should accordingly not be used in such a case. If, on the other hand, one is interested in developing a new forecasting model based on variables from the survey and want to evaluate its out-of-sample forecast performance, the quasi-realtime data set should be very useful. In this case, the issues that we mainly are concerned might distort the analysis, namely seasonal adjustment and standardisation, have been addressed when creating the data set. For this purpose the quasireal-time data should accordingly be close to a perfect substitute to actual real-time data.

\subsection{A Monthly Quasi-Real-Time Data Set}

The questions, indicators and other variables included in the monthly data set are provided in Appendices 1 and 3. We generate 192 vintages of monthly data. The first reflects the Economic Tendency Survey of January 2000. The last reflects the survey of December 2015. Since different questions have been included in the survey at different points in time, the number of variables included in the survey varies with the vintage. The vintage from which a particular question, indicator or other variable is available - as well as the starting point of the time series in question-can also be found in Appendices 1 and 3. For example, the Economic Tendency Indicator (KIFI) is available from the first data vintage, that is, that of January 2000. Its starting date is July 1996 which means that the first vintage has 43 observations. Households' expectations on the variable home loan rate at the 1-, 2and 5-year horizon (questions Q183, Q193 and Q203, see Appendix 3), on the other hand, are available only from the vintage of February 2010; this date also corresponds to the first observations for these three series.

As was described above, many time series have been seasonally adjusted. For individual questions, this is indicated with the suffix " $S$ " in the name of the 
variable. ${ }^{8}$ For example, net figures for the output volume over the past three months in the manufacturing industry are given by BTVI101 and the seasonally adjusted net figures are given by BTVI101S. ${ }^{9}$ It should be noted though that while indicators such as the consumer confidence indicator (BHUSCON) and the Economic Tendency Indicator (KIFI) are based on seasonally adjusted data, they do not have the suffix "S". The seasonal adjustment is conducted on no less than three years of data. This means that in some cases, the first vintage in which a variable is included will differ between the original series and the seasonally adjusted one; in the cases where the first vintage differs, this is indicated with two dates for the first vintage in which the series in question is included. The date for the seasonally adjusted data is indicated with the suffix "S". For example, January 2000 is the first vintage in which BTVI107 is included. The first vintage in which the seasonally adjusted series BTVI107S is included is July 2002 (since the first observation of BTVI107 is July 1999 and seasonal adjustment is conducted using no less than three years of data); see Appendix 1 for details.

Figure 3 shows three different vintages of the Economic Tendency Indicator (KIFI) from the monthly quasi-real-time data set. As can be seen, the three vintages look fairly similar but they are not identical. As an example, we can note that between September 1996 and February 1997, the difference between the January 2006 and December 2015 vintages is small (always less than 0.8 index units). However, between March and August 2000, the difference between the same two vintages is never less than 4 units.

In Fig. 4, different vintages are shown of the seasonally adjusted figures corresponding to the (weighted) share of companies in the construction industry that answered that the weather currently was the main obstacle to increased activity (BBOA1075S). Note that the sample in the figure is January 1988 to December 2000 in order to make differences clearer. ${ }^{10}$ Looking at the figure, we see that there is no difference at all-at any point in time-between the January 2006 and December 2015 vintages. ${ }^{11}$ Comparing these series to the January 2000 vintage though, it is clear that the seasonal adjustment matters from a real-time perspective, even if the differences by no means are dramatic. For example, the seasonally adjusted value for June 1999 is 3 in the January 2000 vintage but 9 in the January 2006 and December 2015 vintages.

Above we have shown just a few examples of how time series look different depending on data vintage. We will not illustrate this issue further since it now should be clear that the real-time aspect of data could matter when using the Economic Tendency Survey for analysis. The full monthly data set can be downloaded from www.konj.se/quasi-real-time-data.

\footnotetext{
8 It also applies to the variables with the suffixes "ORDP", "SYSP", "SYSA" and "PRIA".

9 BTVI101 hence reflects what we above have referred to as "raw data".

${ }^{10}$ For data plotted over the full sample, see Figure 5 in Appendix 4.

11 This owes to the fact that the seasonally adjusted series are rounded to the nearest integer value. This is done in order to follow the methodology used in the Economic Tendency Survey. If the seasonally adjusted series had not been rounded, there would have been minor discrepancies between the January 2006 and December 2015 vintages.
} 


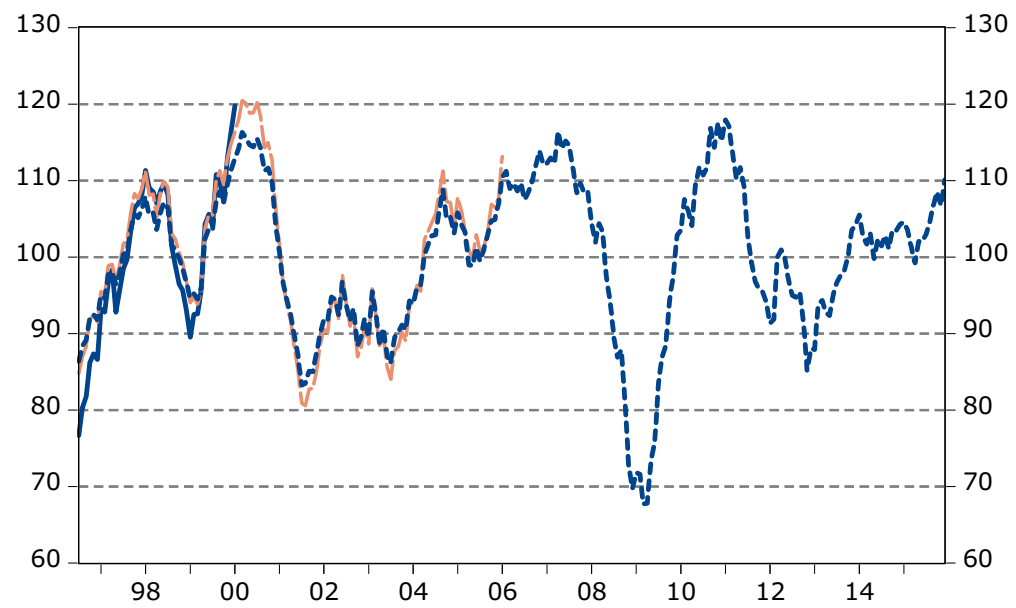

KIFI, January 2000

KIFI, January 2006

KIFI, December 2015

Fig. 3 Different vintages of the Economic Tendency Indicator. Note Index numbers on the vertical axis. "KIFI" is the Economic Tendency Indicator. Data are from the quasi-real-time data vintages of January 2000, January 2006 and December 2015

\subsection{A Quarterly Quasi-Real-Time Data Set}

Turning to the quarterly data, the questions, indicators and other variables included in the data set are given in Appendix 2. As was the case for the monthly data set, both raw and seasonally adjusted data have been made available. And just like above, the seasonally adjusted series have the suffix " $S$ ". It should be noted that the quarterly data set only contains data from the business survey (since it is this part of the survey that differs in January, April, July and October). We generate 64 vintages of quarterly data. The first reflects the Economic Tendency Survey of January 2000. The last reflects the survey of October 2015. Similar to the case of the monthly survey, different questions have been included in the survey at different points in time; the number of variables included in the survey therefore varies with the vintage also in this case. The vintage from which a particular question, indicator or other variable is available - as well as the starting point of the time series in question-can also be found in Appendix 2. The full quarterly data set can be downloaded from www.konj.se/quasi-real-time-data.

\section{Empirical Illustration: Nowcasting GDP Growth Using Indicators}

The main purpose for developing the data sets presented above is to allow for model-based out-of-sample nowcast or forecast evaluations to be conducted in the best possible manner. Variables from the Economic Tendency Survey are often used 


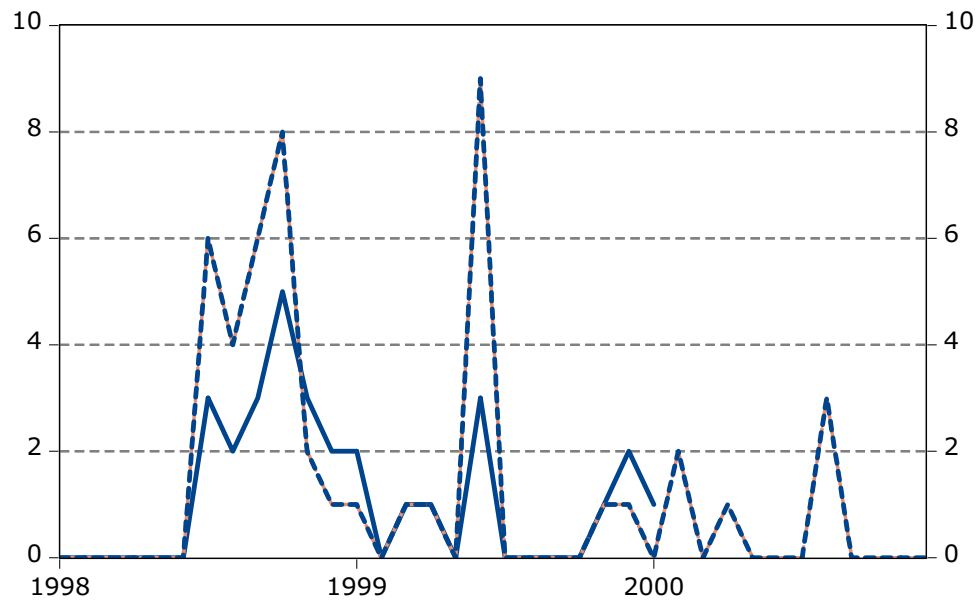

BBOA1075S, January 2000

BBOA1075S, January 2006

BBOA1075S, December 2015

Fig. 4 Different vintages of the share of companies in the construction industry whose main obstacle to increased activity was the weather, January 1998 to December 2000. Note Percent on the vertical axis. Seasonally adjusted data are from the quasi-real-time data vintages of January 2000, January 2006 and December 2015

as explanatory variables in models developed for this purpose since it is assumed that they provide timely information on the economic situation which is relevant to nowcasters/forecasters. However, until recently such evaluations have typically relied on ex post data from the survey since these are the ones that have been available. ${ }^{12}$ For variables that are seasonally adjusted and/or standardised, this introduces an error which could cause, for example, forecast precision being overor understated. If one is unfortunate, this could lead to the wrong conclusions being drawn. Having developed the quasi-real-time data sets for the Economic Tendency Survey, one can now minimise the errors when conducting this type of analysis. We next illustrate this issue in an empirical application where we nowcast Swedish GDP growth.

By "nowcast", we mean that we are trying to predict the GDP growth associated with a certain quarter when standing partway through the quarter in question. ${ }^{13}$ Seeing that GDP is a national accounts variable which tends to be revised as time passes, we follow standard practice and use real-time data on GDP growth for our

\footnotetext{
12 See, for example, Hansson et al. (2005) and Assarsson and Österholm (2015). Österholm (2014) also relied on ex post data but since the analysis was conducted using net figures which had not been seasonally adjusted, this was equivalent to using real-time data (subject to corrected errors).

${ }^{13}$ See, for example, Banbura et al. (2011) and Andersson and den Reijer (2015) for examples of nowcasting.
} 
analysis. ${ }^{14}$ We compare the nowcasting performance of models using the Economic Tendency Indicator and six confidence indicators from the Economic Tendency Survey for Swedish GDP growth in two cases. First, we use ex post data from the Economic Tendency Survey; these are given by the December 2015 vintage. One quarterly time series per variable is constructed by using the February observations for Q1, the May observations for Q2, the July observations for Q3 and the November observations for $\mathrm{Q} 4 .{ }^{15}$ Second, we use the monthly quasi-real-time data described above. In a similar manner to the ex post data, quarterly time series are generated based on the monthly data. However, in this case, one quarterly time series per variable is constructed for each data vintage.

The out-of-sample nowcast exercise is conducted the following way: A number of models (specified below) are used. The first nowcast employs data on GDP growth from 1996Q3 to 2003Q4 which reflect national accounts data that were released in early March 2004. At this point in time, the survey data that would have been available for nowcasting correspond to the Economic Tendency Survey published in February 2004 (where the value for this month is used for 2004Q1 as described above). Based on these data, we estimate the models and a nowcast for 2004Q1 is generated from each model. The sample is then expanded one quarter, the models re-estimated and new nowcasts are generated. This process continues until the end of the sample period; the final nowcast is based on GDP data from 1996Q3 to 2015Q2, which are used to generate a nowcast for 2015Q3. We accordingly evaluate 47 nowcasts for each model.

Two simple models are used as reference points. First, we rely on the model:

$$
g_{t}=c+e_{t}
$$

where $g_{t}=100\left(Y_{t}-Y_{t-1}\right) / Y_{t-1}$, where $Y_{t}$ is GDP in period $t$ and $e_{t}$ is an error term. Since this model's only explanatory variable is a constant, its nowcast will be the estimated historical average. It accordingly provides a natural benchmark for other models to outperform. A model which does not have higher forecast precision than such a simple alternative appears to be of limited usefulness. Concerning the models which do have higher forecast precision than the model in Eq. (1), we say that they have positive nowcast content. ${ }^{16}$ Second, we also employ an AR(1) model:

$$
g_{t}=c+\rho g_{t-1}+e_{t}
$$

Due to its simplicity and flexibility, the AR(1) model is a frequently used benchmark in applied macroeconomic work. $^{17}$

\footnotetext{
${ }^{14}$ The real-time data for GDP which have been used are based on the seasonal adjustment of the National Institute of Economic Research for vintages up to and including the vintage published in November 2010; these data are not identical to those published by Statistics Sweden. Later vintages-starting with that published in March 2011 - are based on the seasonal adjustment of Statistics Sweden.

15 The reason for using this timing is that it reflects how Swedish national accounts are published and, hence, how many forecasters use the data.

16 The terminology is based on Galbraith (2003). In a similar manner, Andersson (2000) required that the forecast provided by the arithmetic mean should be outperformed in order for a model to have forecast memory.

17 See, for example, Mitchell (2009) or Pesaran et al. (2009).
} 
Apart from these two models, we also estimate six models for each set of survey data (that is, ex post and quasi-real-time). Each model has the form

$$
g_{t}=c+b S_{t}+e_{t}
$$

where $S_{t}$ is an indicator based on the survey data.

In addition to these models, we finally report the forecast precision from a naive forecast. This simply states that GDP growth in the present quarter will be the same as that of the previous quarter:

$$
\hat{g}_{t \mid t}=g_{t-1}
$$

where $\hat{g}_{t \mid t}$ is the nowcast of GDP growth at time $t$ made at $t$.

We rely on the mean absolute error (MAE) and root mean square error (RMSE) of the nowcast as our criteria to evaluate the nowcast performance of the models. Defining the nowcast error as $v_{t+i \mid t+i}=g_{t+i}-\hat{g}_{t+i \mid t+i}$, where $g_{t+i}$ is the outcome and $\hat{g}_{t+i \mid t+i}$ the nowcast, these measures are given as

$$
M A E=(1 / n) \sum_{i=0}^{n-1}\left|v_{t+i \mid t+i}\right|
$$

and

$$
R M S E=\sqrt{(1 / n) \sum_{i=0}^{n-1}\left(v_{t+i \mid t+i}\right)^{2}}
$$

Results from this exercise can be found in Table 1. We first turn to the analysis using ex post data which can be found to the left. As can be seen, the MAEs indicate that all versions of Eq. (3) except that relying on BBOACON (the confidence indicator for the construction industry) have higher forecast precision than Eq. (1). Put differently, all investigated variables except BBOACON appear to have positive nowcast content. Comparing the MAEs to each other, we find that the lowest MAE is found for BTVICON (the confidence indicator for the manufacturing industry), closely followed by BHUSCON (the consumer confidence indicator) and KIFI (the Economic Tendency Indicator). Turning to the RMSEs, the results are quite similar. We again find that all versions of Eq. (3) except that relying on BBOACON have higher forecast precision than Eq. (1). In terms of the ranking of the models, this is slightly different from when using the MAEs for evaluation. We now we find that the lowest RMSE is found for BHUSCON, followed by KIFI and BTOTCON (the confidence indicator for the total business sector).

Overall though, differences in forecast precision between most models using survey data are small and should not be over-interpreted. In order to illustrate this, consider the fact that judging purely by the MAEs and RMSEs-as we did aboveall investigated variables from the Economic Tendency Survey except one appear to have positive nowcast content. But what does a formal test have to say about this issue? We assess this by testing whether the differences in nowcast precision between the model in Eq. (1) and the other models are statistically significant. This 
Table 1 RMSEs when nowcasting GDP growth

\begin{tabular}{llllllll}
\hline & \multicolumn{2}{l}{ Ex post data } & & \multicolumn{3}{l}{ Quasi-real-time data } \\
\cline { 2 - 3 } & MAE & RMSE & DM & & MAE & RMSE & DM \\
\hline Eq. (1) [Constant] & 0.587 & 0.803 & - & & 0.587 & 0.803 & - \\
Eq. (2) [AR(1)] & 0.559 & 0.794 & 0.01 & & 0.559 & 0.794 & 0.01 \\
Eq. (3) & & & & & & \\
BHUSCON & 0.501 & 0.671 & $0.19^{*}$ & & 0.482 & 0.653 & $0.22^{*}$ \\
KIFI & 0.503 & 0.685 & $0.18^{*}$ & & 0.494 & 0.678 & $0.19^{* *}$ \\
BTOTCON & 0.512 & 0.701 & $0.15^{*}$ & & 0.508 & 0.695 & $0.16^{*}$ \\
BTVICON & 0.497 & 0.707 & $0.15^{* *}$ & & 0.485 & 0.696 & $0.16^{* *}$ \\
BBOACON & 0.597 & 0.814 & -0.02 & & 0.596 & 0.813 & -0.02 \\
BTJACON & 0.518 & 0.703 & 0.15 & & 0.523 & 0.705 & 0.15 \\
BHANCON & 0.531 & 0.737 & 0.10 & & 0.516 & 0.728 & 0.12 \\
Nä̈ve nowcast & 0.700 & 0.936 & -0.23 & & 0.700 & 0.936 & -0.23 \\
\hline
\end{tabular}

Note "Ex post data" and "Quasi-real-time data" refer to the indicators from the Economic Tendency Survey; data on GDP growth are in all cases real-time data. Variables based on survey data are defined in Appendices 1 and 2. "Naïve nowcast" refers to a nowcast which states that the growth rate of the current quarter will be the same as that of the previous quarter. "DM" is the test statistic from the DieboldMariano test, where the comparison always is made against the model in Eq. (1); ** and * indicate significance at the 5 and $10 \%$ level respectively

is done by conducting Diebold-Mariano tests (Diebold and Mariano 1995) under an assumption of a quadratic loss function. ${ }^{18}$ That is, we run the regression

$$
\left(v_{t \mid t}^{1}\right)^{2}-\left(v_{t \mid t}^{c o m p}\right)^{2}=c+\omega_{t}
$$

where $v_{t \mid t}^{1}$ is the nowcast error from Eq. (1) and $v_{t \mid t}^{\text {comp }}$ the nowcast error from the competing model; $\omega_{t}$ is an error term. The nowcasts from the competing models are based on Eqs. (2), (3) and (4). We test the null hypothesis that the parameter $c$ in Eq. (7) is equal to zero using a $t$ test based on Newey-West standard errors (Newey and West 1987). As can be seen from the table, the Diebold-Mariano test is statistically significant (at the $10 \%$ level or less) for BHUSCON, KIFI, BTOTCON and BTVICON. For BTJACON and BHANCON though, the difference is not statistically significant; this is despite the fact that the model based on BTJACON has an RMSE which is $12 \%$ lower than that of the model in Eq. (1). ${ }^{19}$

The results just discussed illustrate conclusions one might draw from a very simple out-of-sample nowcast exercise where ex post data for the Economic Tendency Survey have been used. So how sensitive are the conclusions drawn with

\footnotetext{
${ }^{18}$ Note that we follow Diebold's (2015) recommendation and rely on the original test and not later, more intricate, versions which take into account that forecasts have been generated by estimated-and in this case also nested-models.

19 This finding should, on the other hand, not necessarily be interpreted as a reason to use Eq. (1) instead of Eq. (3) with BTJACON. A nowcaster choosing between models which are approximately equally likely a priori would be inclined to choose the model with the highest nowcast precision even if this model is not found to significantly outperform the other model(s). For a critical view concerning significance tests, see Armstrong (2007).
} 
respect to the fact that we relied on ex post data? Were MAEs and/or RMSEs overor understated? Were any incorrect conclusions drawn? In order to answer such questions, we next turn to the analysis using quasi-real-time data.

As can be seen from the right part of Table 1, it can first be noted that the MAEs and RMSEs using the quasi-real-time data in all cases are close to those when ex post data were used. In general, both measures tend to be lower when using the quasi-real-time data; the MAE and RMSE are higher only for BTJACON (the confidence indicator in the service sector). Overall though, it seems fair to say that no serious over- or understatement of forecast precision was introduced by using the ex post data. If we look at the relative performance of the different indicators, we see that the ranking of the models is similar; it can be noted though that the best indicator judging by the MAE is now found to be BHUSCON rather than BTVICON (as we found when using the ex post data above) ${ }^{20}$ It should, however, be pointed out once again that the differences in forecast precision between most models are small. Finally, turning to the results from the Diebold-Mariano tests, we see that these are almost identical to when the ex post data were used. One minor difference can be found, namely that for KIFI the null hypothesis can be rejected at the 5\% level (rather than the $10 \%$ level that was the case when employing the ex post data).

Summing up this exercise, we established that there were only minor differences in the results when using quasi-real-time data instead of ex post data. Our findings suggest that for the simple models studied here, one would not have been seriously mislead by using the ex post data. This conclusion should, however, not be interpreted as a reason not to use the quasi-real-time data. Because while we have established that the error committed by using ex post data in this particular application was small, we had to conduct the above analysis to reach this insight. If this had not been done, we simply would not have known this. Using larger and/or more complicated models, results may very well look different. In practice, the researcher never will know exactly how big the error from using ex post data is in a given application unless analysis similar to that in this paper is conducted. To conclude, we note that real-time data have become the benchmark when it comes to certain analysis relying on national accounts data, such as forecasting and nowcasting. We recommend that the quasi-realtime data sets presented in this paper should be employed in a similar manner for analysis relying on the Economic Tendency Survey.

\section{Conclusions}

In this paper we have documented two quasi-real-time data sets of the Economic Tendency Survey. The data sets consist of monthly/quarterly vintages of the most important series of the survey. A natural usage of these data sets is evaluations of model-based nowcasts and forecasts. We have accordingly illustrated how the data sets can be employed by conducting an out-of-sample nowcast exercise for Swedish

\footnotetext{
${ }^{20}$ In addition, BTJACON and BHANCON have also switched places when using the MAE as the evaluation criterion. Using the RMSE as the evaluation criterion, the only difference is that BTJACON and BTVICON have switched places.
} 
GDP growth in which data from the Economic Tendency Survey act as explanatory variables. This shows that several of the studied indicators from the Economic Tendency Survey appear to have positive nowcast content for GDP growth.

While the quasi-real-time data do not solve all problems that the applied researcher using the Economic Tendency Survey might face, it should help address a few of them. The quasi-real-time data should be the natural starting point when conducting, for example, an out-of-sample nowcast or forecast exercise; it is after all the best approximation to real-time data that we have. The data sets should also be useful when studying a range of other questions, including issues concerning the survey itself. For example, one could investigate quality aspects of seasonal adjustment. Such analysis could contribute not only to our understanding of the properties of the time series in the Economic Tendency Survey in particular, but also to a widening regarding our knowledge of the behaviour of data based on similar surveys in general.

Acknowledgements We are grateful to two anonymous referees, Göran Hjelm, Marcus Jansson, Ard den Reijer, Sven-Erik Sveder and seminar participants at the National Institute of Economic Research and the 33rd CIRET Conference "Economic Tendency Surveys and Economic Policy" in Copenhagen for valuable comments.

Open Access This article is distributed under the terms of the Creative Commons Attribution 4.0 International License (http://creativecommons.org/licenses/by/4.0/), which permits unrestricted use, distribution, and reproduction in any medium, provided you give appropriate credit to the original author(s) and the source, provide a link to the Creative Commons license, and indicate if changes were made.

\section{Appendix 1: Variable Names for Indicators and Questions Referring to Businesses Included in the Monthly Data Set}

Total business sector

\begin{tabular}{|c|c|c|c|}
\hline Question/indicator & Name & First obs. & $\begin{array}{l}\text { First } \\
\text { vintage }\end{array}$ \\
\hline $\begin{array}{l}\text { Confidence indicator } \\
\text { Index, mean }=100\end{array}$ & BTOTCON & $1996 \mathrm{~m} 07$ & $2000 \mathrm{~m} 1$ \\
\hline $\begin{array}{l}\text { Demand, present situation assessment } \\
\text { (weighted average of the balances of BTVI104, BBOA104, } \\
\text { BHAN102 and BTJA103) }\end{array}$ & BTOTORDP & $2001 \mathrm{~m} 01$ & $\begin{array}{l}2001 \mathrm{~m} 01 / \\
2004 \mathrm{~m} 01 \mathrm{~s}\end{array}$ \\
\hline $\begin{array}{l}\text { The number of employees in the firm has over the past } \\
3 \text { months: } \\
\text { (weighted average of the balances of BTVI107, BBOA106, } \\
\text { BHAN104 and BTJA105) }\end{array}$ & BTOTSYSP & $2001 \mathrm{~m} 01$ & $\begin{array}{l}2001 \mathrm{~m} 01 / \\
2004 \mathrm{~m} 01 \mathrm{~s}\end{array}$ \\
\hline $\begin{array}{l}\text { The number of employees in the firm is expected in the next } \\
3 \text { months to: } \\
\text { (weighted average of the balances of BTVI204, BBOA204, } \\
\text { BHAN204 and BTJA203) }\end{array}$ & BTOTSYSA & $2001 \mathrm{~m} 01$ & $\begin{array}{l}2001 \mathrm{~m} 01 / \\
2004 \mathrm{~m} 01 \mathrm{~s}\end{array}$ \\
\hline $\begin{array}{l}\text { Prices are expected in the next } 3 \text { months to: } \\
\text { (weighted average of the balances of BTVIPRIA, BBOA202, } \\
\text { BHAN202 and BTJA202) }\end{array}$ & BTOTPRIA & $2010 \mathrm{~m} 05$ & $\begin{array}{l}2010 \mathrm{~m} 05 / \\
2013 \mathrm{~m} 05 \mathrm{~s}\end{array}$ \\
\hline
\end{tabular}


Manufacturing industry

\begin{tabular}{|c|c|c|c|}
\hline Question/indicator & Name & First obs. & $\begin{array}{l}\text { First } \\
\text { vintage }\end{array}$ \\
\hline $\begin{array}{l}\text { Confidence indicator } \\
\text { Index, mean }=100\end{array}$ & BTVICON & 1996m02 & $2000 \mathrm{~m} 01$ \\
\hline $\begin{array}{l}\text { Output volume has over the past } 3 \text { months: } \\
\text { Increased } \\
\text { Unchanged } \\
\text { Decreased }\end{array}$ & BTVI101 & 1996m02 & $2000 \mathrm{~m} 01$ \\
\hline $\begin{array}{l}\text { New orders from the domestic market have } \\
\text { over the past } 3 \text { months: }\end{array}$ & BTVI102 & 1996m02 & $2000 \mathrm{~m} 01$ \\
\hline $\begin{array}{l}\text { Increased } \\
\text { Unchanged } \\
\text { Decreased }\end{array}$ & & & \\
\hline New orders from the export market have ov & BTVI103 & $1996 \mathrm{~m} 02$ & $2000 \mathrm{~m} 01$ \\
\hline
\end{tabular}

New orders from the export market have over the past 3 months:

BTVI103 1996m02 2000m01

Increased

Unchanged

Decreased

New orders have over the past 3 months:

(weighted average of BTVI102 and BTVI103)

BTVIORDP $\quad 1996 \mathrm{~m} 02 \quad 2000 \mathrm{~m} 01$

The total order book is currently:

BTVI104 1996m02 2000m01

Relatively large

Sufficient

Too small

The export order book is currently:

BTVI105 1996m02 2000m01

Relatively large

Sufficient

Too small

Finished inventories are currently:

BTVI106

1996m02

$2000 \mathrm{~m} 01$

Too large

Sufficient

Too small

The number of employees in the firm has over

BTVI107

1999m07 2000m01/ the past 3 months:

$2002 \mathrm{~m} 07 \mathrm{~s}$

Increased

Unchanged

Decreased

Output volume is expected in the next 3 months to:

BTVI201

1996m02 2000m01

Increase

Unchanged

Decrease 


\begin{tabular}{|c|c|c|c|}
\hline Question/indicator & Name & First obs. & $\begin{array}{l}\text { First } \\
\text { vintage }\end{array}$ \\
\hline $\begin{array}{l}\text { Selling prices on the domestic market are expected } \\
\text { in the next } 3 \text { months to: }\end{array}$ & \multirow[t]{4}{*}{ BTVI202 } & \multirow[t]{4}{*}{$1996 \mathrm{~m} 02$} & \multirow[t]{4}{*}{$2000 \mathrm{~m} 01$} \\
\hline Increase & & & \\
\hline Unchanged & & & \\
\hline Decrease & & & \\
\hline $\begin{array}{l}\text { Selling prices on the export market are expected } \\
\text { in the next } 3 \text { months to: }\end{array}$ & \multirow[t]{4}{*}{ BTVI203 } & \multirow[t]{4}{*}{$1996 \mathrm{~m} 02$} & \multirow[t]{4}{*}{$2000 \mathrm{~m} 01$} \\
\hline Increase & & & \\
\hline Unchanged & & & \\
\hline Decrease & & & \\
\hline $\begin{array}{l}\text { Selling prices (in SEK) are expected in the next } 3 \text { months to: } \\
\text { (weighted avereage of BTVI202 and BTVI203) }\end{array}$ & \multirow[t]{4}{*}{ BTVIPRIA } & \multirow[t]{4}{*}{$1996 \mathrm{~m} 02$} & \multirow[t]{4}{*}{$2000 \mathrm{~m} 01$} \\
\hline Increase & & & \\
\hline Unchanged & & & \\
\hline Decrease & & & \\
\hline $\begin{array}{l}\text { The number of employees in the firm is expected } \\
\text { in the next } 3 \text { months to: }\end{array}$ & \multirow[t]{4}{*}{ BTVI204 } & \multirow[t]{4}{*}{$1999 \mathrm{~m} 07$} & \multirow[t]{4}{*}{$\begin{array}{l}2000 \mathrm{~m} 01 / \\
2002 \mathrm{~m} 07 \mathrm{~s}\end{array}$} \\
\hline Increase & & & \\
\hline Unchanged & & & \\
\hline Decrease & & & \\
\hline
\end{tabular}

Three subsectors of the manufacturing industry are also included in the data set: "investment goods", "intermediate goods" and "consumer goods". The questions asked are the same in all cases but the variable names are given with a different prefix. For "investment goods" the prefix is "BINVE", for "intermediate goods" it is "BINTM" and for "consumer goods" it is "BCONS". The question concerning output volume over the past three months is accordingly called BINVE101, BINTM101 and BCONS101 for the three subsectors respectively. The other questions and indicators for these subsectors are named according to the same principle. The first observation of the raw data for the subsectors is in all three cases January 2000. Accordingly, the raw data first appear in the January 2000 vintage and the seasonally adjusted data in the January 2003 vintage.

Construction of buildings and civil engineering

\begin{tabular}{llll}
\hline Question/indicator & Name & First obs. & First vintage \\
\hline Confidence indicator & BBOACON & $1996 \mathrm{~m} 02$ & $2000 \mathrm{~m} 01$ \\
$\begin{array}{l}\text { Index, mean }=100 \\
\text { Building activity has over the past 3 months: }\end{array}$ & BBOA101 & $1996 \mathrm{~m} 02$ & $2000 \mathrm{~m} 01$ \\
Increased & & & \\
Unchanged & & & \\
Decreased & & & \\
\hline
\end{tabular}




\begin{tabular}{llll}
\hline Question/indicator & Name & First obs. & First vintage \\
\hline Tender prices have over the past 3 months: & BBOA102 & $1996 \mathrm{~m} 02$ & $2000 \mathrm{~m} 01$ \\
Increased & & & \\
Unchanged & BBOA103 & $1996 \mathrm{~m} 02$ & $2000 \mathrm{~m} 01$ \\
Decreased & & & \\
The order book has over the past 3 months: & & & \\
Increased & BBOA104 & $1996 \mathrm{~m} 02$ & $2000 \mathrm{~m} 01$ \\
Unchanged & & & \\
Decreased & & & \\
The order book is currently: & & & \\
Increased & BBOA106 & $1996 \mathrm{~m} 02$ & $2000 \mathrm{~m} 01$ \\
Unchanged & & & \\
Decreased \\
The number of employees in the firm has
\end{tabular}
over the past 3 months:

Increased

Unchanged

Decreased

Which factor is currently the main obstacle to increased construction activity?

\begin{tabular}{|c|c|c|c|}
\hline None & BBOA1071 & $1996 \mathrm{~m} 02$ & $2000 \mathrm{~m} 01$ \\
\hline Insufficient demand & BBOA1072 & $1996 \mathrm{~m} 02$ & $2000 \mathrm{~m} 01$ \\
\hline Shortage of plant capacity and/or building materials & BBOA1073 & $1996 \mathrm{~m} 02$ & $2000 \mathrm{~m} 01$ \\
\hline Labour shortage & BBOA1074 & $1996 \mathrm{~m} 02$ & $2000 \mathrm{~m} 01$ \\
\hline Weather & BBOA1075 & $1996 \mathrm{~m} 02$ & $2000 \mathrm{~m} 01$ \\
\hline \multirow[t]{2}{*}{ Financial restrictions } & BBOA1076 & $2003 \mathrm{~m} 05$ & $2003 \mathrm{~m} 05 /$ \\
\hline & & & $2006 \mathrm{~m} 05 \mathrm{~s}$ \\
\hline Other factors & BBOA1077 & $1996 \mathrm{~m} 02$ & $2000 \mathrm{~m} 01$ \\
\hline Construction activity is expected in the next 3 months to: & BBOA201 & $1996 \mathrm{~m} 02$ & $2000 \mathrm{~m} 01$ \\
\hline \multicolumn{4}{|l|}{ Increase } \\
\hline \multicolumn{4}{|l|}{ Unchanged } \\
\hline \multicolumn{4}{|l|}{ Decrease } \\
\hline Tender prices are expected in the next 3 months to: & BBOA202 & $1996 \mathrm{~m} 02$ & $2000 \mathrm{~m} 01$ \\
\hline \multicolumn{4}{|l|}{ Increase } \\
\hline \multicolumn{4}{|l|}{ Unchanged } \\
\hline \multicolumn{4}{|l|}{ Decrease } \\
\hline The order book is expected in the next 3 months to: & BBOA203 & $1996 \mathrm{~m} 02$ & $2000 \mathrm{~m} 01$ \\
\hline \multicolumn{4}{|l|}{ Increase } \\
\hline \multicolumn{4}{|l|}{ Unchanged } \\
\hline \multicolumn{4}{|l|}{ Decrease } \\
\hline $\begin{array}{l}\text { The number of employees in the firm is } \\
\text { expected in the next } 3 \text { months to: }\end{array}$ & BBOA204 & $1996 \mathrm{~m} 02$ & $2000 \mathrm{~m} 01$ \\
\hline \multicolumn{4}{|l|}{ Increase } \\
\hline \multicolumn{4}{|l|}{ Unchanged } \\
\hline Decrease & & & \\
\hline
\end{tabular}


Trade

\begin{tabular}{|c|c|c|c|}
\hline Question/indicator & Name & First obs. & First vintage \\
\hline $\begin{array}{l}\text { Confidence indicator } \\
\text { Index, mean }=100\end{array}$ & BHANCON & $1996 \mathrm{~m} 07$ & $2000 \mathrm{~m} 01$ \\
\hline $\begin{array}{l}\text { The sales volume has over the past } 3 \text { months: } \\
\text { Increased } \\
\text { Unchanged } \\
\text { Decreased }\end{array}$ & BHAN101 & $1996 \mathrm{~m} 07$ & $2000 \mathrm{~m} 01$ \\
\hline $\begin{array}{l}\text { The firm's current sales situation is considered to be: } \\
\text { Good } \\
\text { Satisfactory } \\
\text { Weak }\end{array}$ & BHAN102 & $1996 \mathrm{~m} 07$ & $2000 \mathrm{~m} 01$ \\
\hline $\begin{array}{l}\text { Inventories are currently considered to be: } \\
\text { Too large } \\
\text { Sufficient } \\
\text { Too small }\end{array}$ & BHAN103 & $1996 \mathrm{~m} 07$ & $2000 \mathrm{~m} 01$ \\
\hline $\begin{array}{l}\text { The number of employees has over the past } 3 \text { months: } \\
\text { Increased } \\
\text { Unchanged } \\
\text { Decreased }\end{array}$ & BHAN104 & $1999 \mathrm{~m} 05$ & $\begin{array}{l}2000 \mathrm{~m} 01 / \\
2002 \mathrm{~m} 05 \mathrm{~s}\end{array}$ \\
\hline $\begin{array}{l}\text { The sales volume is expected in the next } 3 \text { months to: } \\
\text { Increase } \\
\text { Unchanged } \\
\text { Decrease }\end{array}$ & BHAN201 & $1996 \mathrm{~m} 07$ & $2000 \mathrm{~m} 01$ \\
\hline $\begin{array}{l}\text { Selling prices are expected in the next } 3 \text { months to: } \\
\text { Increase } \\
\text { Unchanged } \\
\text { Decrease }\end{array}$ & BHAN202 & $2003 \mathrm{~m} 05$ & $\begin{array}{l}2003 \mathrm{~m} 05 / \\
2006 \mathrm{~m} 05 \mathrm{~s}\end{array}$ \\
\hline $\begin{array}{l}\text { Purchases of goods are expected in the next } 3 \text { months to: } \\
\text { Increase } \\
\text { Unchanged } \\
\text { Decrease }\end{array}$ & BHAN203 & $1996 \mathrm{~m} 07$ & $2000 \mathrm{~m} 01$ \\
\hline $\begin{array}{l}\text { The number of employees is expected in the next } 3 \text { months to: } \\
\text { Increase } \\
\text { Unchanged } \\
\text { Decrease }\end{array}$ & BHAN204 & $1999 \mathrm{~m} 05$ & $\begin{array}{l}2000 \mathrm{~m} 01 / \\
2002 \mathrm{~m} 05 \mathrm{~s}\end{array}$ \\
\hline $\begin{array}{l}\text { The firm's sales situation in } 6 \text { months' time is expected to be: } \\
\text { Better } \\
\text { Unchanged } \\
\text { Weaker }\end{array}$ & BHAN205 & $1996 \mathrm{~m} 07$ & $2000 \mathrm{~m} 01$ \\
\hline
\end{tabular}


The subsector "retail trade" is also included in the data set. The questions asked are the same as for "trade" in all cases but the variable names are given with a different prefix, "BDHAN". The question concerning sales volume over the past three months is accordingly called BDHAN101. The other questions and indicators are named according to the same principle. First observations and first vintages for the BDHAN variables are the same as for the BHAN variables.

Private service sector

\begin{tabular}{|c|c|c|c|}
\hline Question/indicator & Name & First obs. & $\begin{array}{l}\text { First } \\
\text { vintage }\end{array}$ \\
\hline $\begin{array}{l}\text { Confidence indicator } \\
\text { Index, mean }=100\end{array}$ & BTJACON & $1996 \mathrm{~m} 01$ & $2000 \mathrm{~m} 01$ \\
\hline $\begin{array}{l}\text { How have the firm's operations developed over the past } 3 \text { months? } \\
\text { Improved } \\
\text { Unchanged } \\
\text { Deteriorated }\end{array}$ & BTJA101 & $2003 \mathrm{~m} 04$ & $\begin{array}{l}2003 \mathrm{~m} 04 / \\
2006 \mathrm{~m} 04 \mathrm{~s}\end{array}$ \\
\hline $\begin{array}{l}\text { Demand for the firm's services has over the past } 3 \text { months: } \\
\text { Increased } \\
\text { Unchanged } \\
\text { Decreased }\end{array}$ & BTJA102 & $2001 \mathrm{~m} 12$ & $\begin{array}{l}2001 \mathrm{~m} 12 / \\
2004 \mathrm{~m} 12 \mathrm{~s}\end{array}$ \\
\hline $\begin{array}{l}\text { The volume of assignments/orders on hand is currently } \\
\text { considered to be: } \\
\text { Relatively large } \\
\text { Sufficient } \\
\text { Too small }\end{array}$ & BTJA103 & $2001 \mathrm{~m} 12$ & $\begin{array}{l}2001 \mathrm{~m} 12 / \\
2004 \mathrm{~m} 12 \mathrm{~s}\end{array}$ \\
\hline $\begin{array}{l}\text { Selling prices have over the past } 3 \text { months: } \\
\text { Increased } \\
\text { Unchanged } \\
\text { Decreased }\end{array}$ & BTJA104 & $2003 \mathrm{~m} 04$ & $\begin{array}{l}2003 \mathrm{~m} 04 / \\
2006 \mathrm{~m} 04 \mathrm{~s}\end{array}$ \\
\hline $\begin{array}{l}\text { The number of employees has over the past } 3 \text { months: } \\
\text { Increased } \\
\text { Unchanged } \\
\text { Decreased }\end{array}$ & BTJA105 & $2001 \mathrm{~m} 12$ & $\begin{array}{l}2001 \mathrm{~m} 12 / \\
2004 \mathrm{~m} 12 \mathrm{~s}\end{array}$ \\
\hline $\begin{array}{l}\text { Demand for the firm's services is expected in the next } \\
3 \text { months to: } \\
\text { Increase } \\
\text { Unchanged } \\
\text { Decrease }\end{array}$ & BTJA201 & $2001 \mathrm{~m} 12$ & $\begin{array}{l}2001 \mathrm{~m} 12 / \\
2004 \mathrm{~m} 12 \mathrm{~s}\end{array}$ \\
\hline $\begin{array}{l}\text { Selling prices are expected in the next } 3 \text { months to: } \\
\text { Increase } \\
\text { Unchanged } \\
\text { Decrease }\end{array}$ & BTJA202 & $2003 \mathrm{~m} 04$ & $\begin{array}{l}2003 \mathrm{~m} 04 / \\
2006 \mathrm{~m} 04 \mathrm{~s}\end{array}$ \\
\hline $\begin{array}{l}\text { The number of employees is expected in the next } 3 \text { months to: } \\
\text { Increase } \\
\text { Unchanged } \\
\text { Decrease }\end{array}$ & BTJA203 & $2001 \mathrm{~m} 12$ & $\begin{array}{l}2001 \mathrm{~m} 12 / \\
2004 \mathrm{~m} 12 \mathrm{~s}\end{array}$ \\
\hline
\end{tabular}




\section{Appendix 2: Variable Names for Indicators and Questions Referring to Businesses Included in the Quarterly Data Set}

Total business sector

\begin{tabular}{|c|c|c|c|}
\hline Question/indicator & Name & $\begin{array}{l}\text { First } \\
\text { obs. }\end{array}$ & $\begin{array}{l}\text { First } \\
\text { vintage }\end{array}$ \\
\hline $\begin{array}{l}\text { Confidence indicator } \\
\text { Index, mean }=100\end{array}$ & BTOTCON & $1996 q 2$ & $2000 q 1$ \\
\hline $\begin{array}{l}\text { Demand, present situation assessment } \\
\text { (weighted average of the balances of BTVI109, BBOA104, } \\
\text { BHAN102 and BTJA103) }\end{array}$ & BTOTORDP & $1996 q 3$ & $2000 q 1$ \\
\hline $\begin{array}{l}\text { The number of employees in the firm has over the past } 3 \text { months: } \\
\text { (weighted average of the balances of BTVI116, BBOA106, } \\
\text { BHAN105 and BTJA106) }\end{array}$ & BTOTSYSP & $1996 q 2$ & $2000 q 1$ \\
\hline $\begin{array}{l}\text { The number of employees in the firm is expected in the next } \\
3 \text { months to: } \\
\text { (weighted average of the balances of BTVI207, BBOA204, } \\
\text { BHAN203 and BTJA203) }\end{array}$ & BTOTSYSA & $1996 q 2$ & $2000 q 1$ \\
\hline $\begin{array}{l}\text { Prices have over the past } 3 \text { months: } \\
\text { (weighted average of the balances of BTVIPRIP, BBOA102, } \\
\text { BHAN107 and BTJA104) }\end{array}$ & BTOTPRIP & $1996 q 2$ & $2000 q 1$ \\
\hline $\begin{array}{l}\text { Prices are expected in the next } 3 \text { months to: } \\
\text { (weighted average of the balances of BTVIPRIA, BBOA202, } \\
\text { BHAN204 and BTJA202) }\end{array}$ & BTOTPRIA & $1996 q 2$ & $2000 q 1$ \\
\hline $\begin{array}{l}\text { Profitability } \\
\text { (weighted average of the balances of BTVI115, BHAN108 and } \\
\text { BTJA105) }\end{array}$ & BTOTLON & $2003 q 2$ & $\begin{array}{l}2003 q 2 / \\
2006 q 2 s\end{array}$ \\
\hline $\begin{array}{l}\text { Labour shortage } \\
\text { (weighted average of the balances of BTVI901, BBOA1074, } \\
\text { BHAN106 and BTJA107) }\end{array}$ & BTOTBRIP & $1996 q 2$ & $2000 q 1$ \\
\hline
\end{tabular}

Manufacturing industry

\begin{tabular}{llll}
\hline Question/indicator & Name & $\begin{array}{l}\text { First } \\
\text { obs. }\end{array}$ & $\begin{array}{l}\text { First } \\
\text { vintage }\end{array}$ \\
\hline $\begin{array}{l}\text { Confidence indicator } \\
\text { Index, mean }=100 \\
\begin{array}{l}\text { Output volume has over the past 3 months: } \\
\text { Increased }\end{array}\end{array}$ & BTVICON & 1964q2 & $2000 \mathrm{q} 1$ \\
$\begin{array}{l}\text { Unchanged } \\
\text { Decreased }\end{array}$ & BTVI101 & $1964 \mathrm{q} 2$ & $2000 \mathrm{q} 1$ \\
\hline
\end{tabular}




\begin{tabular}{llll}
\hline Question/indicator & Name & $\begin{array}{l}\text { First } \\
\text { obs. }\end{array}$ & $\begin{array}{l}\text { First } \\
\text { vintage }\end{array}$ \\
\hline
\end{tabular}

Production capacity has over the past 3 months:

BTVI102 1964q2 2000q1

Increased

Unchanged

Decreased

The firm's production capacity is currently:

BTVI103 1996q2 2000q1

More than sufficient

Sufficient

Not sufficient

Current capacity utilisation is estimated at around:

BTVI104 1996q2 2000q1

......percent

Selling prices (in SEK) on the domestic market have over the past

BTVI105

$1964 q 2 \quad 2000 q 1$ 3 months:

Increased

Unchanged

Decreased

Selling prices (in SEK) on the export market have over the past 3 months:

BTVI106

$1964 q 2 \quad 2000 q 1$

Increased

Unchanged

Decreased

Selling prices (in SEK) have over the past 3 months:

BTVIPRIP $\quad 1964 q 2 \quad 2000 q 1$

(weighted average of balances of BTVI105 and BTVI106)

New orders from the domestic market have over the past 3 months:

BTVI107 1964q2 2000q1

Increased

Unchanged

Decreased

New orders from the export market have over the past 3 months:

BTVI108

$1964 q 2 \quad 2000 q 1$

Increased

Unchanged

Decreased

New orders have over the past 3 months:

BTVIORDP $\quad 1964 q 2 \quad 2000 q 1$

(weighted average of the balances of BTVI107 and BTVI108)

The total order book is currently:

BTVI109 1964q2 2000q1

Relatively large

Sufficient

Too small

The export order book is currently:

BTVI110 1996q2 2000q1

Relatively large

Sufficient

Too small 


\begin{tabular}{llll}
\hline Question/indicator & Name & $\begin{array}{l}\text { First } \\
\text { obs. }\end{array}$ & $\begin{array}{l}\text { First } \\
\text { vintage }\end{array}$ \\
\hline
\end{tabular}

How many production weeks are covered by the current order

BTVI111

$1996 \mathrm{q} 2000 \mathrm{q} 1$ book?

Around ................ weeks

How has the firm's competitive situation changed on the domestic market over the past 3 months?

BTVI112 1996q2 2000q1

Improved

Unchanged

Worsened

How has the firm's competitive situation changed on the EUmarket over the past 3 months?

BTVI113 1996q2 2000q1

Improved

Unchanged

Worsened

How has the firm's competitive situation changed outside the EU

BTVI114

$1996 \mathrm{q} 2000 \mathrm{q} 1$ over the past 3 months?

Improved

Unchanged

Worsened

Current profitability is:

BTVI115 1996q2 2000q1

Good

Satisfactory

Poor

The number of employees in the firm has over the past 3 months:

BTVI116 1978q2 2000q1

Increased

Unchanged

Decreased

Is there currently a shortage of skilled labour?

BTVI117 1964q2 2000q1

Yes

No

Is there currently a shortage of technical staff?

BTVI118 1964q2 2000q1

Yes

No

Is there currently a shortage of other staff?

BTVI119 1996q2 2000q1

Yes

No

Shortage of staff

BTVI901 1995q2 2000q1

(Yes on any of BTVI117-BTVI119) 


\begin{tabular}{llll}
\hline Question/indicator & Name & $\begin{array}{l}\text { First } \\
\text { obs. }\end{array}$ & $\begin{array}{l}\text { First } \\
\text { vintage }\end{array}$ \\
\hline
\end{tabular}

Raw materials inventories are currently:

BTVI120 1964q2 2000q1

Too large

Sufficient

Too small

Finished inventories have over the past 3 months:

BTVI121 1964q2 2000q1

Increased

Unchanged

Decreased

Finished inventories are currently:

BTVI122 1964q2 2000q1

Too large

Sufficient

Too small

Which factor is currently the main obstacle to increased production?

\begin{tabular}{|c|c|c|c|}
\hline None & BTVI123 & $1996 \mathrm{q} 2$ & $2000 q 1$ \\
\hline Insufficient demand & BTVI124 & $1968 \mathrm{q} 2$ & $2000 \mathrm{q} 1$ \\
\hline Shortage of machinery and plant & BTVI125 & $1968 \mathrm{q} 2$ & $2000 q 1$ \\
\hline Labour shortage & BTVI126 & $1968 \mathrm{q} 2$ & $2000 q 1$ \\
\hline Financial restrictions & BTVI127 & $2003 q 3$ & $\begin{array}{l}2003 \mathrm{q} 3 / \\
2006 \mathrm{q} 3 \mathrm{~s}\end{array}$ \\
\hline Other factor & BTVI128 & $1968 \mathrm{q} 2$ & $2000 q 1$ \\
\hline $\begin{array}{l}\text { Production factors as the main obstacle to increased production } \\
\text { (BTVI125 or BTVI126 or BTVI128) }\end{array}$ & BTVIRAS & $1968 \mathrm{q} 2$ & $2000 \mathrm{q} 1$ \\
\hline $\begin{array}{l}\text { Output volume is expected in the next } 3 \text { months to: } \\
\text { Increase } \\
\text { Unchanged } \\
\text { Decrease }\end{array}$ & BTVI201 & $1964 q 1$ & 2000q1 \\
\hline $\begin{array}{l}\text { Production capacity is expected in the next } 3 \text { months to: } \\
\text { Increase } \\
\text { Unchanged } \\
\text { Decrease }\end{array}$ & BTVI202 & $1964 q 2$ & $2000 q 1$ \\
\hline $\begin{array}{l}\text { Selling prices (in SEK) on the domestic market are expected in the } \\
\text { next } 3 \text { months to: }\end{array}$ & BTVI203 & $1964 q 1$ & $2000 \mathrm{q} 1$ \\
\hline Increase & & & \\
\hline Unchanged & & & \\
\hline Decrease & & & \\
\hline $\begin{array}{l}\text { Selling prices (in SEK) on the export market are expected in the } \\
\text { next } 3 \text { months to: }\end{array}$ & BTVI204 & $1964 q 1$ & $2000 q 1$ \\
\hline Increase & & & \\
\hline Unchanged & & & \\
\hline Decrease & & & \\
\hline
\end{tabular}




\begin{tabular}{|c|c|c|c|}
\hline Question/indicator & Name & $\begin{array}{l}\text { First } \\
\text { obs. }\end{array}$ & $\begin{array}{l}\text { First } \\
\text { vintage }\end{array}$ \\
\hline $\begin{array}{l}\text { Selling prices are expected in the next } 3 \text { months to } \\
\text { (weighted average of balances of BTVI203 and BTVI204) }\end{array}$ & BTVIPRIA & $1964 q 1$ & $2000 \mathrm{q} 1$ \\
\hline $\begin{array}{l}\text { New orders from the domestic market are expected in the next } \\
3 \text { months to: }\end{array}$ & BTVI205 & $1964 q 1$ & $2000 q 1$ \\
\hline \multicolumn{4}{|l|}{ Increase } \\
\hline \multicolumn{4}{|l|}{ Unchanged } \\
\hline \multicolumn{4}{|l|}{ Decrease } \\
\hline $\begin{array}{l}\text { New orders from the export market are expected in the next } \\
3 \text { months to: }\end{array}$ & BTVI206 & $1964 q 1$ & $2000 \mathrm{q} 1$ \\
\hline \multicolumn{4}{|l|}{ Increase } \\
\hline \multicolumn{4}{|l|}{ Unchanged } \\
\hline \multicolumn{4}{|l|}{ Decrease } \\
\hline $\begin{array}{l}\text { New orders received are expected in the next } 3 \text { months to: } \\
\text { (weighted average of balances of BTVI205 and BTVI206) }\end{array}$ & BTVIORDA & $1964 q 1$ & $2000 \mathrm{q} 1$ \\
\hline $\begin{array}{l}\text { The number of employees in the firm is expected in the next } \\
3 \text { months to: }\end{array}$ & BTVI207 & $1978 \mathrm{q} 2$ & $2000 \mathrm{q} 1$ \\
\hline \multicolumn{4}{|l|}{ Increase } \\
\hline \multicolumn{4}{|l|}{ Unchanged } \\
\hline Decrease & & & \\
\hline
\end{tabular}

Three subsectors of the manufacturing industry are also included in the data set: "investment goods", "intermediate goods" and "consumer goods". The questions asked are the same in all cases but the variable names are given with a different prefix. For "investment goods" the prefix is "BINVE", for "intermediate goods" it is "BINTM" and for "consumer goods" it is "BCONS". The question concerning output volume over the past three months is accordingly called BINVE101, BINTM101 and BCONS101 for the three subsectors respectively. The other questions and indicators for these subsectors are named according to the same principle. The first observation of variables for the subsectors is in all three cases later than the corresponding variables for "BTVI". However, all subsector variables appear for the first time in the same data vintages as the corresponding BTVI variable.

Construction of buildings and civil engineering

\begin{tabular}{llll}
\hline Question/indicator & Name & First obs. & First vintage \\
\hline Confidence indicator & BBOACON & $1974 \mathrm{q} 2$ & $2000 \mathrm{q} 1$ \\
Index, mean $=100$ & & & \\
Building activity has over the past 3 months: & BBOA101 & $1974 \mathrm{q} 2$ & $2000 \mathrm{q} 1$ \\
Increased & & & \\
Unchanged & & & \\
Decreased & & & \\
\hline
\end{tabular}




\begin{tabular}{|c|c|c|c|}
\hline Question/indicator & Name & First obs. & First vintage \\
\hline $\begin{array}{l}\text { Tender prices have over the past } 3 \text { months: } \\
\text { Increased } \\
\text { Unchanged } \\
\text { Decreased }\end{array}$ & BBOA102 & $1974 q 2$ & $2000 q 1$ \\
\hline $\begin{array}{l}\text { The order book has over the past } 3 \text { months: } \\
\text { Increased } \\
\text { Unchanged } \\
\text { Decreased }\end{array}$ & BBOA103 & $1974 q 2$ & $2000 q 1$ \\
\hline $\begin{array}{l}\text { The order book is currently: } \\
\text { Relatively large } \\
\text { Just right } \\
\text { Too small }\end{array}$ & BBOA104 & $1974 q 2$ & $2000 q 1$ \\
\hline $\begin{array}{l}\text { How many production weeks are covered by the current order } \\
\text { book? }\end{array}$ & BBOA105 & $1996 q 2$ & $2000 q 1$ \\
\hline Around...$\ldots \ldots \ldots \ldots$ weeks & & & \\
\hline $\begin{array}{l}\text { The number of employees in the firm has over the past } \\
3 \text { months: }\end{array}$ & BBOA106 & $1974 q 2$ & $2000 q 1$ \\
\hline
\end{tabular}

Increased

Unchanged

Decreased

Which factor is currently the main obstacle to increased construction activity?

\begin{tabular}{|c|c|c|c|}
\hline None & BBOA1071 & $1996 \mathrm{q} 2$ & $2000 \mathrm{q} 1$ \\
\hline Insufficient demand & BBOA1072 & $1974 q 2$ & $2000 \mathrm{q} 1$ \\
\hline Shortage of plant capacity and/or building materials & BBOA1073 & $1974 q 2$ & $2000 q 1$ \\
\hline Labour shortage & BBOA1074 & $1974 q 2$ & $2000 \mathrm{q} 1$ \\
\hline Weather & BBOA 1075 & $1996 \mathrm{q} 2$ & $2000 \mathrm{q} 1$ \\
\hline Financial restrictions & BBOA1076 & $2003 q 3$ & $\begin{array}{l}2003 \mathrm{q} 3 / \\
2006 \mathrm{q} 3 \mathrm{~s}\end{array}$ \\
\hline Other factors & BBOA1077 & $1974 q 2$ & $2000 q 1$ \\
\hline $\begin{array}{l}\text { Construction activity is expected in the next } 3 \text { months to: } \\
\text { Increase }\end{array}$ & BBOA201 & $1974 q 2$ & $2000 q 1$ \\
\hline \multicolumn{4}{|l|}{ Unchanged } \\
\hline \multicolumn{4}{|l|}{ Decrease } \\
\hline $\begin{array}{l}\text { Tender prices are expected in the next } 3 \text { months to: } \\
\text { Increase }\end{array}$ & BBOA202 & $1974 q 2$ & $2000 \mathrm{q} 1$ \\
\hline \multicolumn{4}{|l|}{ Unchanged } \\
\hline \multicolumn{4}{|l|}{ Decrease } \\
\hline $\begin{array}{l}\text { The order book is expected in the next } 3 \text { months to: } \\
\text { Increase }\end{array}$ & BBOA203 & $1974 q 2$ & $2000 \mathrm{q} 1$ \\
\hline Unchanged & & & \\
\hline Decrease & & & \\
\hline
\end{tabular}




\begin{tabular}{llll}
\hline Question/indicator & Name & First obs. & First vintage \\
\hline The number of employees in the firm is expected in the next & BBOA204 & 1974q2 & 2000q1 \\
3 months to: & & & \\
Increase & & & \\
Unchanged & BBOA205 & $1974 q 2$ & $2000 \mathrm{q} 1$ \\
Decrease & & & \\
Outlook for the construction market a year ahead & & & \\
Improve & & & \\
Unchanged & & & \\
Deteriorate & & &
\end{tabular}

Trade

\begin{tabular}{|c|c|c|c|}
\hline Question/indicator & Name & First obs. & First vintage \\
\hline $\begin{array}{l}\text { Confidence indicator } \\
\text { Index, mean }=100\end{array}$ & BHANCON & $1996 \mathrm{q} 2$ & $2000 q 1$ \\
\hline $\begin{array}{l}\text { The sales volume has over the past } 3 \text { months: } \\
\text { Increased } \\
\text { Unchanged } \\
\text { Decreased }\end{array}$ & BHAN101 & $1996 q 2$ & $2000 q 1$ \\
\hline $\begin{array}{l}\text { The firm's current sales situation is considered to be: } \\
\text { Good } \\
\text { Satisfactory } \\
\text { Weak }\end{array}$ & BHAN102 & $1996 \mathrm{q} 3$ & $2000 q 1$ \\
\hline $\begin{array}{l}\text { Purchases of goods have over the past } 3 \text { months: } \\
\text { Increased } \\
\text { Unchanged } \\
\text { Decreased }\end{array}$ & BHAN103 & $1996 q 2$ & $2000 q 1$ \\
\hline $\begin{array}{l}\text { Inventories are currently considered to be: } \\
\text { Too large } \\
\text { Sufficient } \\
\text { Too small }\end{array}$ & BHAN104 & $1996 \mathrm{q} 2$ & $2000 q 1$ \\
\hline $\begin{array}{l}\text { The number of employees has over the past } 3 \text { months: } \\
\text { Increased } \\
\text { Unchanged } \\
\text { Decreased }\end{array}$ & BHAN105 & $1996 q 2$ & $2000 q 1$ \\
\hline $\begin{array}{l}\text { Does the firm currently have a staff shortage: } \\
\text { Yes } \\
\text { No }\end{array}$ & BHAN106 & $1996 q 2$ & $2000 q 1$ \\
\hline $\begin{array}{l}\text { Selling prices have over the past } 3 \text { months: } \\
\text { Increased } \\
\text { Unchanged }\end{array}$ & BHAN107 & $1996 q 2$ & $2000 \mathrm{q} 1$ \\
\hline
\end{tabular}




\begin{tabular}{|c|c|c|c|}
\hline Question/indicator & Name & First obs. & First vintage \\
\hline $\begin{array}{l}\text { Profitability is currently? } \\
\text { Good } \\
\text { Satisfactory } \\
\text { Weak }\end{array}$ & BHAN108 & $1996 \mathrm{q} 2$ & $2000 \mathrm{q} 1$ \\
\hline $\begin{array}{l}\text { The sales volume is expected in the next } 3 \text { months to: } \\
\text { Increase } \\
\text { Unchanged } \\
\text { Decrease }\end{array}$ & BHAN201 & $1996 \mathrm{q} 1$ & $2000 \mathrm{q} 1$ \\
\hline $\begin{array}{l}\text { Purchases of goods are expected in the next } 3 \text { months to: } \\
\text { Increase } \\
\text { Unchanged } \\
\text { Decrease }\end{array}$ & BHAN202 & $1996 \mathrm{q} 1$ & $2000 \mathrm{q} 1$ \\
\hline $\begin{array}{l}\text { The number of employees is expected in the next } 3 \text { months to: } \\
\text { Increase } \\
\text { Unchanged } \\
\text { Decrease }\end{array}$ & BHAN203 & $1996 \mathrm{q} 2$ & $2000 \mathrm{q} 1$ \\
\hline $\begin{array}{l}\text { Selling prices are expected in the next } 3 \text { months to: } \\
\text { Increase } \\
\text { Unchanged } \\
\text { Decrease }\end{array}$ & BHAN204 & $1996 \mathrm{q} 1$ & $2000 \mathrm{q} 1$ \\
\hline $\begin{array}{l}\text { The firm's sales situation in } 6 \text { months' time is expected to be: } \\
\text { Better } \\
\text { Unchanged } \\
\text { Weaker }\end{array}$ & BHAN205 & $1996 \mathrm{q} 3$ & $2000 \mathrm{q} 1$ \\
\hline
\end{tabular}

The subsector "retail trade" is also included in the data set. The questions asked are the same as for "trade" in all cases but the variable names are given with a different prefix, "BDHAN". The question concerning sales volume over the past three months is accordingly called BDHAN101. The other questions and indicators are named according to the same principle. First observations and first vintages for the BDHAN variables are the same as for the BHAN variables, with one exception: the first observation of BDHAN102 is 1996q2 and the first observation of BHAN102 is 1996q3. 
Private service sector

\begin{tabular}{|c|c|c|c|}
\hline Question/indicator & Name & $\begin{array}{l}\text { First } \\
\text { obs. }\end{array}$ & $\begin{array}{l}\text { First } \\
\text { vintage }\end{array}$ \\
\hline Confidence indicator & BTJACON & $1996 q 1$ & $2000 \mathrm{q} 1$ \\
\hline \multicolumn{4}{|l|}{ Index, mean $=100$} \\
\hline How have the firm's operations developed over the past 3 months? & BTJA101 & $2003 q 2$ & $2003 q 2 /$ \\
\hline Improved & & & $2006 q 2 s$ \\
\hline \multicolumn{4}{|l|}{ Unchanged } \\
\hline \multicolumn{4}{|l|}{ Deteriorated } \\
\hline Demand for the firm's services has over the past 3 months: & BTJA102 & $2003 q 2$ & $2003 q 2 /$ \\
\hline Increased & & & $2006 q 2 s$ \\
\hline \multicolumn{4}{|l|}{ Unchanged } \\
\hline \multicolumn{4}{|l|}{ Decreased } \\
\hline The volume of assignments/orders on hand is currently: & BTJA103 & $2003 q 2$ & $2003 q 2 /$ \\
\hline Relatively large & & & $2006 q 2 s$ \\
\hline \multicolumn{4}{|l|}{ Sufficient } \\
\hline \multicolumn{4}{|l|}{ Too small } \\
\hline Selling prices have over the past 3 months: & BTJA104 & $2003 q 2$ & $2003 q 2 /$ \\
\hline Increased & & & $2006 q 2 s$ \\
\hline \multicolumn{4}{|l|}{ Unchanged } \\
\hline \multicolumn{4}{|l|}{ Decreased } \\
\hline Profitability is currently? & BTJA105 & $2003 q 2$ & $2003 q 2 /$ \\
\hline Good & & & $2006 q 2 s$ \\
\hline \multicolumn{4}{|l|}{ Satisfactory } \\
\hline \multicolumn{4}{|l|}{ Weak } \\
\hline The number of employees has over the past 3 months: & BTJA106 & $2003 q 2$ & $2003 q 2 /$ \\
\hline Increased & & & $2006 q 2 s$ \\
\hline \multicolumn{4}{|l|}{ Unchanged } \\
\hline \multicolumn{4}{|l|}{ Decreased } \\
\hline Does the firm currently have a staff shortage? & BTJA107 & $2003 q 2$ & $2003 q 2 /$ \\
\hline Yes/No & & & $2006 \mathrm{q} 2 \mathrm{~s}$ \\
\hline $\begin{array}{l}\text { If the demand expanded, could you increase your volume of activity } \\
\text { with your present resources? }\end{array}$ & BTJA108 & $2003 q 2$ & $\begin{array}{l}2003 q 2 / \\
2006 q 2 s\end{array}$ \\
\hline \multicolumn{4}{|l|}{ Yes/No } \\
\hline \multirow[t]{2}{*}{ If so, by how much? ...\% } & BTJA109 & $2011 q 3$ & 2011q3/ \\
\hline & & & $2014 q 3 \mathrm{~s}$ \\
\hline \multicolumn{4}{|l|}{ Which factor is currently the main obstacle firm's activity? } \\
\hline None & BTJA110 & $2003 q 2$ & $\begin{array}{l}2003 \mathrm{q} 2 / \\
2006 \mathrm{q} 2 \mathrm{~s}\end{array}$ \\
\hline Insufficient demand & BTJA111 & $2003 q 2$ & $\begin{array}{l}2003 \mathrm{q} 2 / \\
2006 \mathrm{q} 2 \mathrm{~s}\end{array}$ \\
\hline Shortage of plant capacity and/or building materials & BTJA112 & $2003 q 2$ & $\begin{array}{l}2003 q 2 / \\
2006 q 2 s\end{array}$ \\
\hline Labour shortage & BTJA113 & $2003 q 2$ & $\begin{array}{l}2003 q 2 / \\
2006 q 2 s\end{array}$ \\
\hline
\end{tabular}




\begin{tabular}{|c|c|c|c|}
\hline Question/indicator & Name & $\begin{array}{l}\text { First } \\
\text { obs. }\end{array}$ & $\begin{array}{l}\text { First } \\
\text { vintage }\end{array}$ \\
\hline Financial restrictions & BTJA114 & $2003 q 2$ & $\begin{array}{l}2003 \mathrm{q} 2 / \\
2006 \mathrm{q} 2 \mathrm{~s}\end{array}$ \\
\hline Other factors & BTJA115 & $2003 \mathrm{q} 2$ & $\begin{array}{l}2003 \mathrm{q} 2 / \\
2006 \mathrm{q} 2 \mathrm{~s}\end{array}$ \\
\hline $\begin{array}{l}\text { Demand for the firm's services is expected in the next } 3 \text { months } \\
\text { to: }\end{array}$ & BTJA201 & $2003 q 2$ & $\begin{array}{l}2003 \mathrm{q} 2 / \\
2006 \mathrm{q} 2 \mathrm{~s}\end{array}$ \\
\hline \multicolumn{4}{|l|}{ Increase } \\
\hline \multicolumn{4}{|l|}{ Unchanged } \\
\hline \multicolumn{4}{|l|}{ Decrease } \\
\hline $\begin{array}{l}\text { Selling prices are expected in the next } 3 \text { months to: } \\
\text { Increase }\end{array}$ & BTJA202 & $2003 q 2$ & $\begin{array}{l}2003 \mathrm{q} 2 / \\
2006 \mathrm{q} 2 \mathrm{~s}\end{array}$ \\
\hline \multicolumn{4}{|l|}{ Unchanged } \\
\hline $\begin{array}{l}\text { The number of employees is expected in the next } 3 \text { months to: } \\
\text { Increase } \\
\text { Unchanged } \\
\text { Decrease }\end{array}$ & BTJA203 & $2003 q 2$ & $\begin{array}{l}2003 q 2 / \\
2006 q 2 s\end{array}$ \\
\hline $\begin{array}{l}\text { Demand for the firm's services in } 6 \text { months' time is expected } \\
\text { to: }\end{array}$ & BTJA204 & $2003 q 2$ & $\begin{array}{l}2003 \mathrm{q} 2 / \\
2006 \mathrm{q} 2 \mathrm{~s}\end{array}$ \\
\hline \multicolumn{4}{|l|}{ Increase } \\
\hline Unchanged & & & \\
\hline Decrease & & & \\
\hline
\end{tabular}

\section{Appendix 3: Variable Names for Questions and Indicators Referring to Households and the Entire Economy Included in the Monthly Data Set}

\begin{tabular}{|c|c|c|c|}
\hline Question/indicator & Name & First obs. & $\begin{array}{l}\text { First } \\
\text { vintage }\end{array}$ \\
\hline Consumer confidence indicator & BHUSCON & $1993 \mathrm{~m} 01$ & $2000 \mathrm{~m} 01$ \\
\hline Consumer macro index & BHUSMIKRO & $1993 \mathrm{~m} 01$ & $2000 \mathrm{~m} 01$ \\
\hline Consumer micro index & BHUSMAKRO & $1993 \mathrm{~m} 01$ & $2000 \mathrm{~m} 01$ \\
\hline Economic tendency indicator & KIFI & 1996m07 & $2000 \mathrm{~m} 01$ \\
\hline $\begin{array}{l}\text { How does the financial situation of your household now } \\
\text { compare with what it was } 12 \text { months ago? Has it...? }\end{array}$ & Q010 & 1993m01 & $2000 \mathrm{~m} 01$ \\
\hline \multicolumn{4}{|l|}{ Got a lot better } \\
\hline \multicolumn{4}{|l|}{ Got a little better } \\
\hline \multicolumn{4}{|l|}{ Stayed the same } \\
\hline \multicolumn{4}{|l|}{ Got a little worse } \\
\hline \multicolumn{4}{|l|}{ Got a lot worse } \\
\hline Don't know & & & \\
\hline
\end{tabular}




\begin{tabular}{lll}
\hline Question/indicator & Name First obs. $\begin{array}{l}\text { First } \\
\text { vintage }\end{array}$ \\
\hline
\end{tabular}

How do you think the financial position of your household will change $\quad$ Q020 $1993 \mathrm{~m} 01 \quad 2000 \mathrm{~m} 01$ over the next 12 months? Will it...?

Get a lot better

Get a little better

Stay the same

Get a little worse

Get a lot worse

Don't know

How do you think the general economic situation in this country has $\quad$ Q030 $1993 \mathrm{~m} 01 \quad 2000 \mathrm{~m} 01$ changed over the last 12 months? Has it...?

Got a lot better

Got a little better

Stayed the same

Got a little worse

Got a lot worse

Don't know

How do you think the general economic situation in this country will develop over the next 12 months? Will it...?

Q040 1993m01 2000m01

Get a lot better

Get a little better

Stay the same

Get a little worse

Get a lot worse

Don't know

Compared with 12 months ago, do you find that prices in general are ...? Q050 1993m01 2000m01

Very much higher

Quite a bit higher

A little higher

About the same

Lower

Don't know

Compared with 12 months ago, how much higher in percent do you think that prices are now?

(mean, extreme values excluded)

Compared to the situation today, do you think that at in the next

Q060 1993m01 2000m01

12 months prices in general will ...?

Q053 2001m12 2001m12

Increase faster

Increase at the same rate

Increase at a slower rate

Stay about the same

Fall slightly

Don't know

Compared with today, how much in percent do you think that prices will go up (i.e. the rate of inflation 12 months from now)?

(mean, extreme values excluded) 
Question/indicator

Name First obs. First

vintage

How do you think the level of unemployment in the country will change Q070

$1993 \mathrm{~m} 012000 \mathrm{~m} 1$

over the next 12 months? Will it...?

Increase sharply

Increase slightly

Remain the same

Fall slightly

Fall sharply

Don't know

Do you think there is an advantage for people to make major purchases (furniture, washing machines, TV sets etc.) at the present time?

Q080 1993m01 2000m1

Yes, now is the right time

It is neither the right time or the wrong time

No, it is the wrong time, purchase should be postponed

Don't know

Over the next 12 months, how do you think the amount of money you will spend on major purchases will compare with what you spent over

Q090 1993m01 2000m1 the last 12 months? Will it be...?

Much more

A little more

About the same

A little less

Much less

Don't know

In the view of the general economic situation, do you think this is:...?

Q100 1993m01 2000m1

A very good time to save

Quite a good time to save

Neither a good, nor an unfavourable time to save

Rather an unfavourable time to save

A very unfavourable time to save

Don't know

Over the next 12 months, how likely are you to be able to save any

Q110 1993m01 2000m1 money?

Very likely

Fairly likely

Fairly unlikely

Very unlikely

Don't know 


\begin{tabular}{|c|c|c|c|}
\hline Question/indicator & Name & $\begin{array}{l}\text { First } \\
\text { obs. }\end{array}$ & $\begin{array}{l}\text { First } \\
\text { vintage }\end{array}$ \\
\hline $\begin{array}{l}\text { Which of these statements best describe the present financial situation of your } \\
\text { household? }\end{array}$ & Q120 & $1993 \mathrm{~m} 01$ & $2000 \mathrm{~m} 1$ \\
\hline \multicolumn{4}{|l|}{ We are saving a lot } \\
\hline \multicolumn{4}{|l|}{ We are saving a little } \\
\hline \multicolumn{4}{|l|}{ We are just managing to make ends meet on our income } \\
\hline \multicolumn{4}{|l|}{ We have to draw on our savings } \\
\hline \multicolumn{4}{|l|}{ We are running into debt } \\
\hline Don't know & & & \\
\hline How likely are you to buy a car within the next 12 months? ${ }^{1}$ & Q130 & $1996 \mathrm{~m} 01$ & $2000 \mathrm{~m} 1$ \\
\hline
\end{tabular}

Very likely

Fairly likely

Fairly unlikely

Very unlikely

Don't know

Are you planning to purchase or build a home within the next 12 months (to live in $\quad$ Q140 $\quad 1996 \mathrm{~m} 01 \quad 2000 \mathrm{~m} 1$ yourself, for a member of your family, as a holiday home, to let etc.)?

Yes, definitely

Possibly

Probably not

Definitely not

Don't know

Over the next 12 months, how likely are you to spend any large sums of money on Q150 $1996 \mathrm{~m} 01-2000 \mathrm{~m} 1$ home improvements such as central heating, sanitary ware etc.?

Very likely

Fairly likely

Fairly unlikely

Very unlikely

Don't know

Compared with 12 months ago, is the risk that you will become unemployed...? $\quad$ Q160 $\quad 2001 \mathrm{~m} 11 \quad 2004 \mathrm{~m} 11$

A lot greater

A little greater

About the same

A little less

A lot less

No opinion

Today the variable home loan rate is $\mathrm{xx} \%$. How high do you expect the variable home loan rate to be in:

1 year's time

Q183 2010m02 2010m02

(mean, extreme values excluded)

2 years' time

Q193 2010m02 2010m02

(mean, extreme values excluded)

5 years' time

Q203 2010m02 2010m02

(mean, extreme values excluded)

Notes Before July 2002, question Q130 concerned plans within 24 months instead of 12 months. Balance for questions Q010-Q040 and Q070-Q120 is chained in December 2001 with data from Statistics Sweden. Balance for questions Q130-Q150 chained in December 2001 with data from Statistics Sweden 


\section{Appendix 4}

\section{See Fig. 5.}

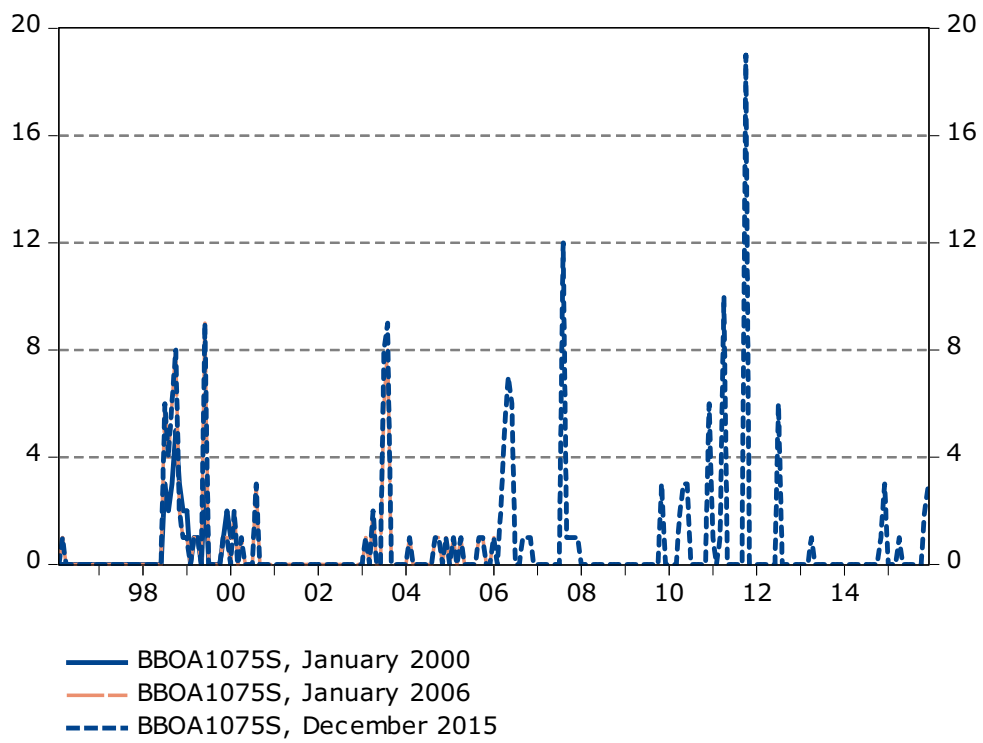

Fig. 5 Different vintages of the share of companies in the construction industry whose main obstacle to increased activity was the weather, February 1996 to December 2015. Note Percent on the vertical axis. Seasonally adjusted data. Data are from the quasi-real-time data vintages of January 2000, January 2006 and December 2015

\section{References}

Andersson, M. K. (2000). Do long-memory models have long memory? International Journal of Forecasting, 16, 121-124.

Andersson, M. K., \& den Reijer, A. H. J. (2015). Nowcasting. Sveriges Riksbank Economic Review, 1, 75-89.

Armstrong, J. S. (2007). Significance tests harm progress in forecasting. International Journal of Forecasting, 23, 321-327.

Assarsson, B., \& Österholm, P. (2015). Do Swedish confidence indicators do what they are intended to do? Applied Economics Quarterly, 61, 391-404.

Banbura, M., Giannone, D., \& Reichlin, L. (2011). Nowcasting. In M. P. Clements \& D. F. Hendry (Eds.), The Oxford handbook of economic forecasting. New York: Oxford University Press.

Croushore, D., \& Stark, T. (2001). A real-time data set for macroeconomists. Journal of Econometrics, 105, 111-130.

Diebold, F. X. (2015). Comparing predictive accuracy, twenty years later: A personal perspective on the use and abuse of Diebold-Mariano tests. Journal of Business and Economic Statistics, 33, 1-8.

Diebold, F. X., \& Mariano, R. S. (1995). Comparing predictive accuracy. Journal of Business and Economic Statistics, 13, 253-263.

Diebold, F. X., \& Rudebusch, G. D. (1991). Forecasting output with the composite leading index: A realtime analysis. Journal of the American Statistical Association, 86, 603-610. 
Galbraith, J. W. (2003). Content horizons for univariate time series forecasts. International Journal of Forecasting, 19, 43-55.

Hansson, J., Jansson, P., \& Löf, M. (2005). Business survey data: Do they help in forecasting GDP growth? International Journal of Forecasting, 21, 377-389.

Herrmann, H., Orphanides, A., \& Siklos, P. (2005). Real-time data and monetary policy. North American Journal of Economics and Finance, 16, 271-276.

Mitchell, J. (2009). Where are we now? The UK recession and nowcasting GDP growth using statistical models. National Institute Economic Review, 209, 60-69.

National Institute of Economic Research (2013). User Guide to the Economic Tendency Survey. http:// www.konj.se/user-guide-economic-tendency-survey.

Newey, W. K., \& West, K. D. (1987). A simple, positive semi-definite, heteroskedasticity and autocorrelation consistent covariance matrix. Econometrica, 55, 703-708.

Orphanides, A. (2001). Monetary policy rules based on real-time data. American Economic Review, 91, 964-985.

Österholm, P. (2014). Survey data and short-term forecasts of Swedish GDP growth. Applied Economics Letters, 21, 135-139.

Pesaran, M. H., Schuermann, T., \& Smith, L. V. (2009). Forecasting economic and financial variables with global VARs. International Journal of Forecasting, 25, 642-675. 